\title{
A Multi-Center Study of $A C E$ and the Risk of Late-Onset Alzheimer's Disease
}

\author{
Olivia Belbin ${ }^{\mathrm{a}, \mathrm{b}, 1}$, Kristelle Brown ${ }^{\mathrm{a}, 1}$, Hui Shi ${ }^{\mathrm{a}}$, Christopher Medway ${ }^{\mathrm{a}}$, Richard Abraham ${ }^{\mathrm{c}}$, Peter \\ Passmore $^{\mathrm{d}}$, David Mann ${ }^{\mathrm{e}}$, A. David Smith ${ }^{\mathrm{f}}$, Clive Holmes ${ }^{\mathrm{g}}$, Bernadette McGuinness ${ }^{\mathrm{d}}$, David Craig ${ }^{\mathrm{d}}$, \\ Donald Warden $^{\mathrm{g}}$, Reinhard Heun ${ }^{\mathrm{h}}$, Heike Kölsch ${ }^{\mathrm{i}}$, Seth Love ${ }^{\mathrm{j}}$, Noor Kalsheker ${ }^{\mathrm{a}}$, Julie Williams ${ }^{\mathrm{c}}$, \\ Michael J. Owen ${ }^{\mathrm{c}}$, Minerva Carrasquillo ${ }^{\mathrm{b}}$, Steven Younkin ${ }^{\mathrm{b}}$, Kevin Morgan $^{\mathrm{a}, 2, *}$ \\ and Patrick G. Kehoe $\mathrm{j}^{\mathrm{j}, 2}$ \\ ${ }^{a}$ Department of Clinical Chemistry, Institute of Genetics, Queen's Medical Centre, University of Nottingham, \\ Nottingham, $U K$ \\ ${ }^{\mathrm{b}}$ Department of Neuroscience, Mayo Clinic, Jacksonville, FL, USA \\ ${ }^{\mathrm{c}}$ Medical Research Council Centre for Neuropsychiatric Genetics and Genomics, Department of Psychological \\ Medicine and Neurology, School of Medicine, Cardiff University, Cardiff, UK \\ ${ }^{\mathrm{d}}$ Department of Geriatric Medicine, The Queen's University of Belfast, Belfast, UK \\ ${ }^{\mathrm{e}}$ Greater Manchester Neurosciences Centre, University of Manchester, Manchester, UK \\ ${ }^{\mathrm{f}}$ Memory Assessment and Research Centre, University of Southampton, Southampton, UK \\ g OPTIMA, University Department of Pharmacology, Oxford, UK \\ ${ }^{\mathrm{h}}$ Department of Old Age Psychiatry, Queen Elizabeth Psychiatric Hospital, Birmingham, UK \\ ${ }^{\mathrm{i}}$ University of Bonn, Bonn, Germany \\ ${ }^{\mathrm{j} S c h o o l ~ o f ~ C l i n i c a l ~ S c i e n c e, ~ I n s t i t u t e ~ o f ~ C l i n i c a l ~ N e u r o s c i e n c e s, ~ U n i v e r s i t y ~ o f ~ B r i s t o l, ~ F r e n c h a y ~ H o s p i t a l, ~}$ \\ Bristol, UK
}

Handling Associate Editor: Francesco Panza

Accepted 28 December 2010

\begin{abstract}
A key pathological feature of late-onset Alzheimer's disease (LOAD) is the abnormal extracellular accumulation of the amyloid- $\beta(A \beta)$ peptide. Thus, altered $A \beta$ degradation could be a major contributor to the development of LOAD. Variants in the gene encoding the $A \beta$-degrading enzyme, angiotensin-1 converting enzyme (ACE) therefore represent plausible candidates for association with LOAD pathology and risk. Following Alzgene meta-analyses of all published case-control studies, the $A C E$ variants rs4291 and rs1800764 showed significant association with LOAD risk. Furthermore $A C E$ haplotypes are associated with both plasma ACE levels and LOAD risk. We tested three $A C E$ variants (rs4291, rs4343, and rs 1800764) for association with LOAD in ten Caucasian case-control populations $(n=8,212)$. No association was found using multiple logistic models (all $p>0.09$ ). We found no population heterogeneity (all $p>0.38$ ) or evidence for association with LOAD risk following meta-analysis of the ten populations for rs4343 (OR = 1.00), rs4291 (OR = 0.97), or rs1800764 (OR = 0.99). Although we found no haplotypic association in our complete dataset $(p=0.51)$, a significant global haplotypic $p$-value was observed in one population $(p=0.007)$ due to an association of the $\mathrm{H} 3$ haplotype $(\mathrm{OR}=0.72, p=0.02)$ and a trend towards an association of $\mathrm{H} 4(\mathrm{OR}=1.38, p=0.09)$ and $\mathrm{H} 7$
\end{abstract}

\footnotetext{
1 These authors contributed equally to this work.

2 These authors were both principal investigators for this study.

*Correspondence to: Kevin Morgan. E-mail: Kevin.Morgan@ nottingham.ac.uk.
} 
$(\mathrm{OR}=2.07, p=0.08)$ although these did not survive Bonferroni correction. Previously reported associations of $A C E$ variants with LOAD will be diminished following this study. At best, $A C E$ variants have modest effect sizes, which are likely part of a complex interaction between genetic, phenotypic and pharmacological effects that would be undetected in traditional case-control studies.

Keywords: Alzheimer's disease, angiotensin-1 converting enzyme, haplotype, heterogeneity, late onset, meta-analysis

\section{INTRODUCTION}

Late-onset Alzheimer's disease (LOAD; MIM 104300) is the most common form of dementia, accounting for almost two-thirds of all dementia cases. Its key pathological features include the formation of intracellular neurofibrillary tangles comprised of microtubule-associated tau, abnormal extracellular accumulations of amyloid- $\beta(A \beta)$ peptide in the form of characteristic senile plaques and in most LOAD cases, deposition of intracerebrovascular $A \beta$ in the form of cerebral amyloid angiopathy [1, 2]. It is increasingly recognized that altered degradation and clearance of $A \beta$ is likely to be of importance in the development and progression of LOAD [3] and that this may be contributed to by both environmental and genetic factors. Cumulative evidence from in vitro, in vivo, and ex vivo studies now strongly support the role of ACE (EC 3.4.15.1), a zinc metalloprotease widely expressed in the brain, as an $A \beta$ degrading enzyme (reviewed in [4]). Taken together with the observation that increased ACE levels and activity are observed in LOAD brains (reviewed in [5]) and are associated with increased plasma levels of $A \beta[6]$ and reduced levels of $A \beta$ in CSF [7, 8], these all point to the likely involvement of ACE in A $\beta$-related pathology in AD. This is further supported by evidence that variation in the gene encoding ACE (ACE; OMIM 106180), may play a role in LOAD pathology and modify LOAD risk. For example, the insertion/deletion (indel) of a $287 \mathrm{bp}$ Alu repeat in intron 16 (rs1799752 Alu I/D) of ACE, and perhaps the most widely studied for LOAD association, is predicted to explain $29-47 \%$ of the variation in plasma ACE levels [9-11]. In their meta-analysis of 39 case-control series, comprising 6,037 LOAD cases and 12,099 controls, Lehmann et al. reported that homozygotes for the $A l u$ deletion were at reduced risk of LOAD $(p=0.0004)$, while heterozygotes were at increased risk [12], thus supporting a genetic association of $A C E$ with LOAD. The fact that the indel does not account for all of the observed variation in ACE levels suggests that other functional ACE variants may be present and in turn associated with ACE levels and/or LOAD risk.
The APOE $\varepsilon 4$ allele (107741) remains the most widely studied and accepted susceptibility gene for LOAD since its first report as a candidate gene almost 20 years ago $[13,14]$. The remaining genetic component of AD risk may involve many genes, each with individually small-to-moderate effect sizes that interact to produce greater effects on disease susceptibility and/or disease modification. However, detection and confirmation of the involvement of genes with these effect sizes requires very large sample sizes. For example, over the last two decades, 664 different genes and almost 3,000 variants have been investigated as susceptibility factors for LOAD risk [15] and until recently, the majority of these studies have been relatively underpowered, often resulting in inconclusive or inconsistent results for the majority of putative candidate genes. AlzGene (http://www.Alzgene.org) [15] was designed and established to resolve this problem to some extent by regularly performing meta-analyses of published data as it emerged to continually compile a list of "Top LOAD genes" that show the strongest associations in LOAD. A relatively constant member of this list has been ACE for which two (rs4291 and rs 1800764) of the six variants studied show significant association with LOAD risk following the AlzGene meta-analyses based on total sample sizes of $n=10,588$ and $n=4,756$, respectively. Notably, rs1800764 has also been associated with elevated CSF $A \beta_{42} / A \beta_{40}$ ratio [7].

Despite the large number of reported independent genetic associations between $A C E$ variants and LOAD in the last decade (22 out of 55 populations published to-date; for details see AlzGene), few studies utilized more comprehensive haplotype approaches [7, 8, 16-19]. Keavney and colleagues identified seven haplotypes in a Caucasian British population derived from data from ten polymorphisms spanning $26 \mathrm{~kb}$ of $A C E$. From these haplotypes, they constructed a cladogram that contained three main branches (clades A, B, and C), which accounted for $90 \%$ of the observed haplotypes. Clade A has since been associated with low plasma ACE levels and increased risk of LOAD [16], clades B and C with higher ACE levels [19-21], and clade $\mathrm{C}$ with increased risk for LOAD in fami- 
Table 1

Details of samples used in this study

\begin{tabular}{|c|c|c|c|c|c|c|c|c|c|c|c|}
\hline \multirow[t]{2}{*}{ Ethnicity } & \multirow[t]{2}{*}{ Sample } & \multirow[t]{2}{*}{ Series } & \multicolumn{2}{|c|}{$n$} & \multirow[b]{2}{*}{ Total } & \multicolumn{2}{|c|}{ Mean age } & \multicolumn{2}{|c|}{$\%$ Female } & \multicolumn{2}{|c|}{$\% \mathrm{E} 4+$} \\
\hline & & & LOAD & CTRL & & LOAD & CTRL & LOAD & CTRL & LOAD & CTRL \\
\hline \multirow{7}{*}{$\begin{array}{l}\text { Caucasian } \\
\text { European }\end{array}$} & \multirow[t]{5}{*}{ ART } & Belfast & 238 & 236 & 474 & 78.3 & 76.1 & 0.66 & 0.65 & 0.58 & 0.28 \\
\hline & & Bonn & 175 & 198 & 373 & 75.9 & 70.9 & 0.76 & 0.49 & 0.55 & 0.27 \\
\hline & & Nottingham/Manchester & 381 & 102 & 483 & 71.0 & 72.6 & 0.54 & 0.34 & 0.62 & 0.23 \\
\hline & & Oxford & 173 & 205 & 378 & 72.7 & 77.3 & 0.56 & 0.57 & 0.64 & 0.25 \\
\hline & & Southampton & 230 & 145 & 375 & 80.6 & 75.8 & 0.58 & 0.49 & $0.47 *$ & 0.26 \\
\hline & MRC & UK & 816 & 959 & 1,775 & 81.5 & 76.6 & 0.72 & 0.64 & 0.63 & 0.24 \\
\hline & Sweden & Sweden & 156 & 59 & 215 & 77.4 & 73.9 & 0.70 & 0.41 & 0.68 & 0.31 \\
\hline \multirow{3}{*}{$\begin{array}{l}\text { Caucasian } \\
\text { North American }\end{array}$} & \multirow{3}{*}{ Mayo Clinic } & Autopsy-confirmed & 592 & 374 & 966 & 81.2 & 75.7 & 0.60 & 0.43 & 0.60 & 0.23 \\
\hline & & Jacksonville & 608 & 602 & 1,210 & 78.1 & 78.0 & 0.62 & 0.60 & 0.62 & 0.26 \\
\hline & & Rochester & 561 & 1,402 & 1,963 & 79.5 & 78.4 & 0.62 & 0.54 & 0.56 & 0.25 \\
\hline Caucasian & All & Total & 3,930 & 4,282 & 8,212 & 78.6 & 76.9 & 0.64 & 0.56 & 0.61 & 0.25 \\
\hline
\end{tabular}

* APOE $\varepsilon 4$ status was unknown for $50 \%$ of LOAD samples from Southampton.

The number of LOAD patients (LOAD) and controls (CTRL), mean age-at-diagnosis, percentage that are female and percentage that possess at least one copy of the $A P O E \varepsilon 4$ allele are given for each individual and pooled series. Mean age is given as age-at-diagnosis/entry.

lies [18]. Kehoe and colleagues also analyzed seven variants within ACE (rs4363, rs4362, rs4343, rs4331, rs4309, rs4291, rs1800764) that formed ten haplotypes with an LD structure that enabled the selection of three 'tagging' variants (rs4291, rs4343 and rs1800764) [8]. The most frequent haplotype (H1) contained the previously reported $\mathrm{AD}$-associated ('risk') $A C E$ indel I allele [22], while the $\mathrm{H} 2$ haplotype contained the ("protective') D allele [8]. Some indication that the indel was not the only functional $A C E$ variant involved in LOAD pathogenesis came from H5 (also containing the I allele) which was also associated with a reduced risk of LOAD [8].

In line with the previous haplotype and cladistic approaches described, we have used the three tagging variants rs4291, rs4343, and rs1800764 to investigate the association of $A C E$ with LOAD in our large multicenter cohort comprising ten case-control series, nine of which do not overlap with those previously published. This represents the largest study to-date to investigate the effects of $A C E$ haplotypes in LOAD.

\section{MATERIALS AND METHODS}

\section{European patient samples}

Informed consent was obtained from all subjects included in this study, which was approved by the local Ethics Committee. This European Caucasian cohort combined three case control sample collections; 1) the Alzheimer's Research Trust (ART) Collaborative Sample Collection (1,197 LOAD patients and 886 controls) supplied from six ART network centers across the UK; 2) the Medical Research Council (MRC) Collabora- tive Sample Collection collected from both community and hospital settings in the UK (816 LOAD patients and 959 controls); and 3) a Swedish sample collection (156 LOAD patients and 59 controls). It must be noted that nine of the ten case-control series used in this cohort do not overlap with those previously published in case-control association studies of $A C E$ variants. The remaining series (Oxford) has previously been reported with respect to the $A C E$ indel (rs1799752) but not for the three tagging SNPs investigated here. A summary of patient details from each centre is shown in Table 1.

\section{US patient samples}

A total of 4,139 Caucasian samples were obtained with written consent from the Mayo Clinic, USA. These samples included 592 autopsy-confirmed AD patients and 374 autopsy-confirmed controls (AUT), 1,169 clinically diagnosed LOAD patients, and 976 controls from Mayo Clinic Jacksonville (JS) and Mayo Clinic, Rochester (RS). None of the samples used in this cohort overlap with those previously published in case-control association studies of $A C E$ variants. Further information regarding these samples can be found in Table 1.

\section{LOAD diagnosis}

The majority of samples were diagnosed possible or probable AD $(n=3,215)$ or control $(n=3,968)$ using NINCDS-ADRDA criteria [23]. The remaining samples were histopathologically confirmed as definite AD $(n=1,091)$ or control $(n=476)$ using NINCDS- 
ADRDA (AUT) or CERAD criteria (ART) [24]. All patients with evidence of an autosomal dominant AD trait, where a first-degree relative had been diagnosed with $\mathrm{AD}$ or where there was evidence for other causes of dementia were excluded.

\section{Genotyping}

Genotyping data from the ART samples was obtained using fluorescently-labeled (VIC or FAM) allele-specific TaqMan probes that were designed by $\mathrm{ABI}$; all assays performed by Geneservice (Cambridge, UK). In addition to assay controls incorporated by Geneservice, $15 \%$ of the samples assayed were sequenced for genotype at source, $10 \%$ of samples were assayed in duplicate for quality assurance. Data were only accepted when there was $100 \%$ concordance between duplicates. All genotype plots were subjected to quality control upon receipt and assays were only accepted when call rates were above $95 \%$. A detailed description of the ascertainment and assessment of the MRC sample collection has been reported previously [25]. The data from the Swedish samples was generated using the Dynamic Allele-Specific Hybridization (DASH) method as described elsewhere [8]. The Mayo Clinic samples were genotyped using TaqMan ${ }^{\circledR}$ SNP Genotyping Assays in an ABI PRISM ${ }^{\circledR}$ 7900HT Sequence Detection System with 384-Well Block Module from Applied Biosystems. All variants passed the $p>0.01$ cut-off for deviation from HardyWeinberg equilibrium as suggested by Wigginton et al. when investigating $>100$ samples [26].

\section{Single variant analysis}

Odds ratios and $95 \% \mathrm{CI}$ were calculated by binary logistic regression (allelic dose model) using the logistic command in PLINK software [27]. The covariates age-at-onset (where unknown, age-at-death minus the 8 year average disease duration was used), carriage of the $A P O E \& 4$ allele and gender were added into the model using the - covar command. The total dataset was also tested for association by binary logistic regression under dominant and recessive models adjusted for covariates using StatsDirect v2.5.8. For meta-analyses, summary ORs, 95\% CI and BreslowDay tests were calculated under the DerSimonian and Laird (1986) random-effects model using StatsDirect v2.5.8 software.

\section{Haplotype association}

Haplotype frequencies were estimated using the expectation-maximization approach implemented in the haplo.em function of Haplo.stats v1.2.2 [28] using $\mathrm{R}$ programming software. Global haplotype association and individual haplotype score tests adjusted for $A P O E \varepsilon 4$ dose, gender and age-at-diagnosis were performed using the haplo.score function of Haplo.stats v1.2.2.

\section{RESULTS}

We tested three $A C E$ variants for association with LOAD in our seven European and three North American case-control series (series details are shown in Table 1). Genotype and allele counts for each series are shown in Table 2. We first tested for association with LOAD in each case-control series by logistic regression using an additive/allelic dosage model correcting for gender, age-at-diagnosis and possession of at least one copy of the APOE $\varepsilon 4$ allele as covariates (Table 2). None of the variants were associated with LOAD risk in any series (all $p>0.09$ ). We also tested for association the three variants in all ten series pooled $(n=8,212)$, but again found no association (all $p>0.18$ ). Since some genetic variants may exert dominant or recessive effects we also performed logistic regression for the total dataset using these models but found no association with LOAD risk (all $p>0.36$ ). We also tested for association of all three variants with LOAD in individuals not possessing the APOE $\varepsilon 4$ allele in all series (1,495 LOAD, 3,175 controls), but found no association (all $p>0.13$; data not shown). In order to determine whether the lack of observation could be attributed to population heterogeneity, we performed meta-analyses of each variant testing for association in the combined data from all ten series using a DerSimonion-Laird random effects model to estimate a pooled odds ratio and testing for heterogeneity between series using the Breslow-Day test (Fig. 1). We found no evidence for population heterogeneity (all $p>0.38$ ) or for association of $\mathrm{rs} 4343(\mathrm{OR}=1.00$, $p=0.90), \mathrm{rs} 4291(\mathrm{OR}=0.97, p=0.47)$, or $\mathrm{rs} 1800764$ $(\mathrm{OR}=0.99, p=0.72)$ with LOAD risk.

In an attempt to replicate previous findings that the two most common haplotypes ( $\mathrm{H} 1$ and $\mathrm{H} 2)$ are significantly associated with opposing risk for LOAD [8], we constructed haplotypes using the three tagging variants. As shown in Table 3, the haplotype frequencies were comparable across all series and are consistent with previous studies [8]. In order to limit the number 
Table 2

Association of $A C E$ variants rs4291, rs4343, and rs1800764 with LOAD

\begin{tabular}{|c|c|c|c|c|c|c|c|c|c|}
\hline \multirow[t]{2}{*}{ Series } & \multirow{2}{*}{$\begin{array}{c}\text { MAF } \\
\text { LOAD : CON }\end{array}$} & \multicolumn{3}{|c|}{ LOAD } & \multicolumn{3}{|c|}{$\mathrm{CON}$} & \multicolumn{2}{|c|}{ Logistic regression } \\
\hline & & Maj & Het & Min & Maj & Het & Min & OR $(95 \% \mathrm{CI})$ & $p$ \\
\hline \multicolumn{10}{|l|}{ rs4343 (G: A) } \\
\hline Belfast (474) & $0.51: 0.56$ & 60 & 113 & 65 & 50 & 109 & 77 & $0.82(0.63-1.07)$ & 0.14 \\
\hline Bonn (373) & $0.52: 0.48$ & 42 & 84 & 49 & 56 & 93 & 49 & $1.17(0.85-1.62)$ & 0.33 \\
\hline Notts./Manch. (483) & $0.49: 0.51$ & 92 & 197 & 87 & 28 & 42 & 31 & $0.90(0.64-1.25)$ & 0.52 \\
\hline Oxford (378) & $0.47: 0.48$ & 50 & 84 & 38 & 57 & 98 & 50 & $0.88(0.64-1.21)$ & 0.43 \\
\hline Southampton (375) & $0.45: 0.45$ & 68 & 116 & 46 & 45 & 67 & 32 & $1.01(0.72-1.42)$ & 0.93 \\
\hline $\operatorname{MRC}(1,775)$ & $0.50: 0.49$ & 205 & 358 & 200 & 233 & 444 & 216 & $1.05(0.90-1.22)$ & 0.51 \\
\hline Sweden (226) & $0.48: 0.49$ & 40 & 81 & 35 & 19 & 22 & 18 & $1.22(0.75-1.97)$ & 0.42 \\
\hline AUT (966) & $0.47: 0.46$ & 166 & 283 & 129 & 112 & 167 & 85 & $1.02(0.84-1.25)$ & 0.88 \\
\hline JS $(1,210)$ & $0.48: 0.49$ & 159 & 302 & 132 & 172 & 295 & 125 & $1.05(0.95-1.16)$ & 0.30 \\
\hline RS $(1,963)$ & $0.48: 0.46$ & 144 & 259 & 145 & 336 & 693 & 344 & $1.04(0.87-1.24)$ & 0.67 \\
\hline All Additive $(8,212)$ & $0.49: 0.49$ & 1026 & 1877 & 926 & 1108 & 2030 & 1027 & $0.99(0.93-1.05)$ & 0.75 \\
\hline All Dominant & & & & & & & & $1.02(0.91-1.14)$ & 0.75 \\
\hline All Recessive & & & & & & & & $1.02(0.90-1.14)$ & 0.80 \\
\hline \multicolumn{10}{|l|}{ rs4291 (A:T) } \\
\hline Belfast (474) & $0.37: 0.32$ & 96 & 110 & 32 & 114 & 91 & 28 & $1.28(0.96-1.70)$ & 0.09 \\
\hline Bonn (373) & $0.35: 0.36$ & 71 & 81 & 19 & 83 & 87 & 27 & $0.84(0.60-1.20)$ & 0.35 \\
\hline Notts./Manch. (483) & $0.37: 0.31$ & 159 & 158 & 60 & 48 & 44 & 10 & $1.31(0.92-1.87)$ & 0.13 \\
\hline Oxford (378) & $0.35: 0.39$ & 71 & 75 & 22 & 75 & 97 & 29 & $0.94(0.67-1.31)$ & 0.88 \\
\hline Southampton (375) & $0.37: 0.42$ & 92 & 106 & 32 & 50 & 65 & 28 & $0.74(0.52-1.05)$ & 0.09 \\
\hline $\operatorname{MRC}(1,775)$ & $0.37: 0.36$ & 323 & 341 & 117 & 364 & 416 & 118 & $1.00(0.85-1.16)$ & 0.91 \\
\hline Sweden (226) & $0.37: 0.40$ & 59 & 78 & 19 & 26 & 19 & 14 & $0.77(0.47-1.23)$ & 0.27 \\
\hline AUT (966) & $0.37: 0.38$ & 242 & 256 & 85 & 143 & 171 & 57 & $0.93(0.76-1.14)$ & 0.50 \\
\hline $\mathrm{JS}(1,210)$ & $0.37: 0.39$ & 236 & 292 & 78 & 217 & 294 & 88 & $0.96(0.80-1.16)$ & 0.58 \\
\hline $\operatorname{RS}(1,963)$ & $0.35: 0.35$ & 241 & 246 & 70 & 586 & 628 & 178 & $0.94(0.80-1.10)$ & 0.42 \\
\hline All Additive $(8,212)$ & $0.36: 0.37$ & 1590 & 1743 & 534 & 1706 & 1912 & 577 & $0.99(0.92-1.05)$ & 0.67 \\
\hline All Dominant & & & & & & & & $0.95(0.86-1.06)$ & 0.36 \\
\hline All Recessive & & & & & & & & $0.97(0.84-1.12)$ & 0.68 \\
\hline \multicolumn{10}{|l|}{ rs1800764 (T:C) } \\
\hline Belfast (474) & $0.41: 0.40$ & 82 & 117 & 39 & 92 & 98 & 45 & $1.03(0.76-1.35)$ & 0.84 \\
\hline Bonn (373) & $0.43: 0.44$ & 53 & 92 & 29 & 66 & 91 & 41 & $0.86(0.61-1.20)$ & 0.37 \\
\hline Notts./Manch. (483) & $0.43: 0.42$ & 124 & 183 & 70 & 32 & 52 & 16 & $1.08(0.76-1.53)$ & 0.66 \\
\hline Oxford (378) & $0.44: 0.46$ & 55 & 84 & 34 & 59 & 104 & 42 & $0.96(0.69-1.33)$ & 0.96 \\
\hline Southampton (375) & $0.47: 0.52$ & 60 & 124 & 46 & 39 & 62 & 44 & $0.85(0.61-1.20)$ & 0.37 \\
\hline $\operatorname{MRC}(1,775)$ & $0.44: 0.43$ & 262 & 378 & 170 & 316 & 451 & 176 & $1.07(0.93-1.25)$ & 0.34 \\
\hline Sweden (226) & $0.43: 0.45$ & 46 & 84 & 25 & 22 & 19 & 16 & $0.77(0.48-1.26)$ & 0.30 \\
\hline AUT (966) & $0.47: 0.48$ & 169 & 276 & 137 & 104 & 180 & 87 & $1.02(0.80-1.14)$ & 0.78 \\
\hline JS $(1,210)$ & $0.45: 0.47$ & 179 & 308 & 113 & 167 & 296 & 130 & $0.95(0.80-1.14)$ & 0.57 \\
\hline RS $(1,963)$ & $0.43: 0.43$ & 183 & 261 & 109 & 462 & 655 & 272 & $1.00(0.86-1.15)$ & 0.96 \\
\hline All Additive $(8,212)$ & $0.44: 0.44$ & 1213 & 1907 & 772 & 1359 & 2008 & 869 & $1.00(0.94-1.07)$ & 0.95 \\
\hline All Dominant & & & & & & & & $1.02(0.92-1.14)$ & 0.69 \\
\hline All Recessive & & & & & & & & $0.97(0.86-1.10)$ & 0.64 \\
\hline
\end{tabular}

Designated major : minor alleles for each variant are shown in parentheses after the variant name in the first column. The number of samples in each series is shown in parentheses after the series name. The minor allele frequency (MAF) and genotype counts in LOAD and controls (CON) for major allele homozygotes (Maj), heterozygotes (Het) and minor allele homozygotes (Min) are provided for each series. Odds ratios (ORs), 95\% confidence intervals $(\mathrm{CI})$ and $p$-values $(p)$ were calculated for each series using a binary logistic regression additive model. The total pooled data (All) was also tested for association using dominant and recessive models. All logistic regression models included age-at-onset, gender and APOE $\varepsilon 4$ allele as covariates.

of tests used, global association of the six haplotypes in each series were tested and individual haplotypes only tested for association for populations with a global $p$ value $<0.05$. A significant global haplotypic $p$-value was observed in the MRC sample only $(p=0.007)$, largely to the protective association of $\mathrm{H} 3(\mathrm{OR}=0.72$, $p=0.02)$ and the trend towards a risky association of $\mathrm{H} 4(\mathrm{OR}=1.38, p=0.09)$ and $\mathrm{H} 7(\mathrm{OR}=2.07, p=0.08)$, associations that were not previously observed by Kehoe and colleagues [8]. The global haplotypic $p$ value for our complete dataset $(n=7,557)$ was not significant $(p=0.51)$, and the individual haplotypic ORs observed in our complete dataset for the two most common haplotypes gave weaker ORs compared to those observed by Kehoe et al. in their complete dataset $(\mathrm{H} 1: \mathrm{OR}=1.0$ vs $1.2, \mathrm{H} 2: \mathrm{OR}=0.96$ vs 0.80 [8]). 


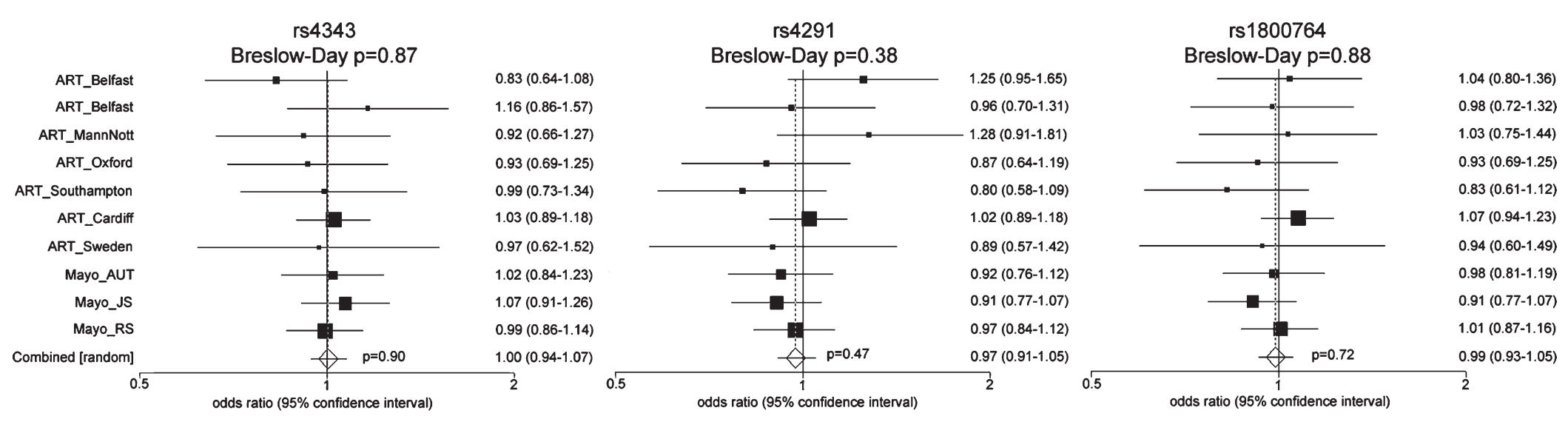

Fig. 1. Forest plots for meta-analysis for each variant. ORs (boxes) and $95 \% \mathrm{CI}$ (whiskers) are plotted for each series and shown on the right of each plot. Combined OR is the overall OR calculated by the meta-analysis using a random effects model. $P$-values from Breslow-Day tests of heterogeneity and meta-analysis are provided. 
Table 3

Association of $A C E$ haplotypes with LOAD

\begin{tabular}{|c|c|c|c|c|c|c|}
\hline \multirow[t]{2}{*}{ Series } & \multirow[t]{2}{*}{ Haplotype* } & \multicolumn{2}{|c|}{ Frequency } & \multirow[t]{2}{*}{ OR } & \multirow[t]{2}{*}{$95 \% \mathrm{CI}$} & \multirow[t]{2}{*}{$p$-value } \\
\hline & & LOAD & CTRL & & & \\
\hline \multirow{6}{*}{$\begin{array}{l}\text { ART } \\
\quad \text { global } p \text {-value }=0.27\end{array}$} & H1-AAT & $973(0.46)$ & $810(0.47)$ & 0.96 & $0.83-1.10$ & \\
\hline & $\mathrm{H} 2-\mathrm{GTC}$ & $722(0.34)$ & $596(0.34)$ & 1.04 & $0.90-1.21$ & \\
\hline & H3-GAT & $236(0.11)$ & $157(0.09)$ & 1.25 & $0.99-1.59$ & \\
\hline & H4-GAC & $236(0.11)$ & $270(0.16)$ & 0.78 & $0.57-1.07$ & \\
\hline & H7-AAC & $44(0.02)$ & $35(0.02)$ & 0.89 & $0.52-1.52$ & \\
\hline & H5-ATC & $30(0.01)$ & $29(0.02)$ & 0.76 & $0.41-1.41$ & \\
\hline \multirow{6}{*}{$\begin{array}{l}\text { MRC } \\
\quad \text { global } p \text {-value }=0.007\end{array}$} & H1-AAT & $671(0.47)$ & $760(0.47)$ & 1.00 & $0.85-1.18$ & 0.99 \\
\hline & H2-GTC & $500(0.35)$ & $551(0.34)$ & 1.05 & $0.88-1.25$ & 0.59 \\
\hline & H3-GAT & $129(0.09)$ & $174(0.11)$ & 0.72 & $0.54-0.96$ & 0.02 \\
\hline & H4-GAC & $87(0.06)$ & $83(0.05)$ & 1.38 & $0.95-1.99$ & 0.09 \\
\hline & H7-AAC & $20(0.01)$ & $24(0.02)$ & 2.07 & $0.92-4.63$ & 0.08 \\
\hline & H5-ATC & $23(0.02)$ & $19(0.01)$ & 0.88 & $0.40-1.93$ & 0.75 \\
\hline \multirow{6}{*}{$\begin{array}{l}\text { Sweden } \\
\quad \text { global } p \text {-value }=0.86\end{array}$} & H1-AAT & $144(0.47)$ & $54(0.47)$ & 1.37 & $0.57-3.28$ & \\
\hline & H2-GTC & $115(0.37)$ & $45(0.39)$ & 0.70 & $0.18-2.76$ & \\
\hline & H3-GAT & $32(0.10)$ & $9(0.08)$ & 1.18 & $0.72-1.95$ & \\
\hline & H4-GAC & $13(0.04)$ & $4(0.03)$ & 1.02 & $0.15-7.01$ & \\
\hline & H7-AAC & $6(0.02)$ & $2(0.02)$ & 0.81 & $0.50-1.31$ & \\
\hline & H5-ATC & $0(0.00)$ & $0(0.00)$ & NA & NA & \\
\hline \multirow{6}{*}{$\begin{array}{l}\text { Mayo Clinic } \\
\text { global } p \text {-value }=0.31\end{array}$} & H1-AAT & $1478(0.45)$ & $2043(0.45)$ & 1.01 & $0.91-1.12$ & \\
\hline & H2-GTC & $1140(0.34)$ & $1593(0.35)$ & 0.92 & $0.83-1.02$ & \\
\hline & H3-GAT & $350(0.11)$ & $439(0.10)$ & 1.05 & $0.88-1.24$ & \\
\hline & H4-GAC & $212(0.06)$ & $272(0.06)$ & 1.03 & $0.83-1.28$ & \\
\hline & H7-AAC & $79(0.02)$ & $83(0.02)$ & 1.45 & $1.00-2.09$ & \\
\hline & H5-ATC & $46(0.01)$ & $61(0.01)$ & 1.38 & $0.85-2.21$ & \\
\hline \multirow{6}{*}{$\begin{array}{l}\text { All } \\
\qquad \text { global } p \text {-value }=0.51\end{array}$} & H1-AAT & $3267(0.46)$ & $3667(0.46)$ & 1.00 & $0.93-1.07$ & \\
\hline & H2-GTC & $2477(0.34)$ & $2785(0.35)$ & 0.97 & $0.90-1.04$ & \\
\hline & H3-GAT & $746(0.11)$ & 779 (0.10) & 1.03 & $0.92-1.17$ & \\
\hline & H4-GAC & $420(0.06)$ & $472(0.06)$ & 1.03 & $0.88-1.20$ & \\
\hline & H7-AAC & $152(0.02)$ & $139(0.02)$ & 1.28 & $0.97-1.68$ & \\
\hline & H5-ATC & $96(0.01)$ & $114(0.01)$ & 1.05 & $0.75-1.47$ & \\
\hline
\end{tabular}

* Order of variants in haplotype is as follows rs4343, rs4291, rs1800764.

Haplotypes are numbered according to their frequency in the Kehoe et al. study [8] (only haplotypes with a frequency $>1 \%$ in this study are shown). Haplotype frequencies are shown for the total dataset and in each of the individual series. A haplotype score test was used to calculate a "global $p$-value": for the association of the haplotypes in the total dataset and in each of the individual series. ORs, $95 \%$ confidence intervals and $p$-values are shown for the individual haplotypes in the MRC series only due to the significant global $p$-value.

$\mathrm{NA}=$ Not applicable. Since H5 was not observed, we were unable to test for association of H5 with LOAD in the Swedish series.

Therefore, these data do not replicate the previously reported association of the Alu indel [12], which tags H1.

\section{DISCUSSION}

We have conducted a large case-control study of three haplotype tagging variants in the LOAD candidate gene, $A C E$, that has previously been associated with LOAD risk [8, 29-34]. Meta-analyses of ten casecontrol series totaling 3,930 LOAD and 4,282 controls showed no population heterogeneity (all $p>0.38$ ) or evidence for association of $\mathrm{rs} 4343(\mathrm{OR}=1.00$, $p=0.90)$, rs4291 (OR $=0.97, p=0.47)$ or $\mathrm{rs} 1800764$ $(\mathrm{OR}=0.99, p=0.72)$ with LOAD risk.

We also tested for association of six $A C E$ haplotypes with LOAD, but found no evidence for association in the total dataset (global $p=0.51$ ). However, we did observe a significant global haplotypic $p$-value of 0.007 in one of the series (the MRC population: 1,430 LOAD patients and 1,611 controls) from the UK, which was largely due to a novel protective association of $\mathrm{H} 3$, the haplotype containing the major allele (G-A-T) at all three variants $(9 \%$ LOAD, $11 \%$ Controls, $\mathrm{OR}=0.72, p=0.02$ ). However, this association was not observed in any of the other case-control populations (all $p>0.07$ ) or in the pooled dataset $(p=0.58)$. Indeed the directionality of ORs observed in all other populations was opposite to that seen for $\mathrm{H} 3$ $(\mathrm{OR}=1.03-1.25)$, but none produced significant findings. The modest $p$-value $(p=0.03)$ for association of H3 with LOAD, which would not survive Bonferroni correction for the six haplotypes studied $(p<0.008)$ along with the lack of association of $\mathrm{H} 3$ in the other nine populations studied here or in previously pub- 
lished studies suggests that the significance of this association should be treated with caution.

The lack of association in any of our ten series for the two $A C E$ variants that have been significantly associated with LOAD following AlzGene meta-analyses is perhaps not surprising. None of the eight Caucasian populations used previously to study rs4291 and included in AlzGene showed significant association for $\mathrm{AD}$, and only one [35] of the seven Caucasian populations used to study rs1800764 showed significant association (OR $=0.86,95 \%$ CI 0.74-0.99). Despite this, AlzGene reported significant association for both rs4291 (OR $=0.87,95 \%$ CI 0.80-0.95) and rs 1800764 $(\mathrm{OR}=0.84,95 \% \mathrm{CI} 0.77-0.92)$ prior to this study. This is largely due to the fact that there was a consistently similar directionality of the ORs in the majority of the Caucasian populations previously used to study rs4291 and rs1800764, and the resulting increase in sample size achieved by analyzing the studies together provides sufficient power to detect association. When the present data is eventually incorporated into Alzgene, these overall associations will likely diminish further towards the null. However, the fact that we also observed same direction ORs in seven out of ten series for rs4291 and six out of ten series for rs 1800764 , raises the possibility that a true association of modest effect size $(\mathrm{OR} \sim 0.90)$ is present, but which requires even larger studies to gain sufficient power for detection.

It is possible that the initial association may have, by chance, been the result of an over-estimation of the effect size of these variants that has since diminished in subsequent follow-up case-control studies. For example, in the case of rs4291, the initial study reported ORs ranging from $0.76-0.84$ in four Caucasian populations each consisting of $\sim 400$ subjects [8]. In comparison, the four subsequent Caucasian studies (all of equal or larger size than the initial study populations) reported ORs ranging from $0.76-1.00$ [31, 32, 36, 37], and here we report ORs ranging from $0.80-1.28$ in ten populations of equal or larger size than the initial study thus further diminishing the effect size. The same appears true for rs 1800764 where the initial study reported ORs ranging from 0.74-0.84 [8], compared to ORs ranging from 0.80-1.09 in subsequent follow-up studies [31, $38,39]$ and in the ORs $0.83-1.07$ reported here. This further supports the need for multiple, large followup studies and meta-analyses of all data to reduce the likelihood of an over-estimation of the effect size.

Failure to detect association could also be explained by these variants merely tagging one or more truly functional variants. In such instances, the corresponding degree of linkage disequilibrium between these variants could differ between series leading to weaker and/or opposing effects. However, given the Caucasian background of all these series and the lack of significant population heterogeneity or association with LOAD risk for any variant in any individual population, this possibility seems unlikely.

If $A C E$ variants modify LOAD risk this effect may be dependent on interactions with other environmental/phenotypic background. For example, ACE mediates hypertensive effects by its function on angiotensin I to convert it to the vasoactive angiotensin II [4]. Thus the co-occurrence of hypertension in subgroups of $\mathrm{AD}$ patients and controls and this being treated to varying extents by drugs that target the pathway in which ACE is functional is likely to be a confounding variable in studies for $A C E$. Indeed, studies of $\mathrm{AD}$ brain tissue have shown that while $A C E$ genotypes did not influence levels or activity of brain ACE [40], rs4343 and rs1800764 have been associated with soluble $A \beta$ levels [41], and exposure of neuronal SH-SY5Y cell lines to oligomeric $A \beta_{1-42}$ for $24 \mathrm{~h}$ resulted in significant increases in ACE protein level and activity [41]. These collectively suggest that, along with previous evidence of elevated ACE activity in AD brain [40, 42], there could be phenotypic-specific post-translational changes to ACE that contribute to AD pathogenesis. Further information supporting this are the findings of Ellul and colleagues [43]. They noted in a longitudinally assessed clinical cohort, that drugs affecting the Renin Angiotensin System, in which ACE is very important, can slow the rates of deterioration of $\mathrm{AD}$ and could serve as a confounder in clinical outcome measurement in clinical trials. The possibility of phenotype-specific pharmacogenetic considerations are also reinforced by findings from a recent GWAS [44] of two youngonset hypertension populations totaling 1,023 subjects that reported eight $A C E$ variants were significantly associated with ACE activity and rs4343 showing the strongest association $\left(p=3.0 \times 10^{-25}\right)$. In the same study an association between blood type and ACE activity in an independent young-onset hypertension family study $(n=428)$ was reported and showed a potential differential blood pressure response to antihypertensive treatment (ACE inhibitors) in subjects dependent on $A C E$ genotype. This latter observation is particularly important in view of findings from a number of observational studies where anti-hypertensive treatments such as inhibitors of ACE activity (i.e., ACE-inhibitors) or of angiotensin II function (i.e., angiotensin II receptor antagonists - ARAs) appeared to be protective against the development of and/or 
progression of LOAD and mild cognitive impairment (MCI) [45-51].

These data do not replicate previously reported haplotype associations with LOAD risk in a large case-control series of 3,930 LOAD patients and 4,282 controls. However, it is clear that when considered alongside data from other disciplines, these findings contribute just one important part of what appears to be a highly complex interaction between $A C E$ genetics, phenotype and pharmacological effects in $\mathrm{AD}$ and which traditional case-control studies are not equipped to unpick. Larger studies which would include richer phenotypic data that would allow for more accurate adjustment for confounders and where possible incorporation of additional measurements specific to candidate gene function (e.g., qPCR, protein based measurements, etc.), would likely increase the chances of unpicking the real genetic involvement of many current candidate genes.

\section{ACKNOWLEDGMENTS}

Samples from the National Cell Repository for Alzheimer's Disease (NCRAD) were used in this study. We thank contributors, including the Alzheimer's Disease Centers who collected samples used in this study, as well as patients and their families, whose help and participation made this work possible. We also thank Jonathan A. Prince (Center for Genomics and Bioinformatics, Karolinska Institute, Stockholm, Sweden) for supplying the genotype data for the case-control series from Sweden. This work was supported by grants from the US National Institutes of Health, NIA R01 AG18023 (Steven G. Younkin); Mayo Alzheimer's Disease Research Center, P50 AG16574 (Steven G. Younkin); The Mayo Clinic sample collection was funded by the Mayo Clinic Mayo Alzheimer's Disease Patient Registry, U01 AG06576 and US National Institute on Aging, AG25711, AG17216, AG03949. Samples from the National Cell Repository for Alzheimer's Disease (NCRAD), which receives government support under a cooperative agreement grant (U24AG21886) awarded by the National Institute on Aging (NIA), were used in this study. This project was also generously supported by the Robert and Clarice Smith Postdoctoral Fellowship (M.M.C.); Robert and Clarice Smith and Abigail Van Buren Alzheimer's Disease Research Program (Steven G. Younkin) and by the Palumbo Professorship in Alzheimer's Disease Research (Steven G. Younkin). K.M. is funded by the Alzheimer's Research Trust and the Big Lottery Fund. P.G.K. is funded by the Sigmund Gestetner Foundation.

Authors' disclosures available online (http://www. j-alz.com/disclosures/view.php?id=720).

\section{REFERENCES}

[1] Walsh DM, Selkoe DJ (2004) Deciphering the molecular basis of memory failure in Alzheimer's disease. Neuron 44, 181193.

[2] Love S, Miners S, Palmer J, Chalmers K, Kehoe P (2009) Insights into the pathogenesis and pathogenicity of cerebral amyloid angiopathy. Front Biosci 14, 4778-4792.

[3] Miners JS, Baig S, Palmer J, Palmer LE, Kehoe PG, Love S (2008) Abeta-degrading enzymes in Alzheimer's disease. Brain Pathol 18, 240-252.

[4] Kehoe PG, Miners S, Love S (2009) Angiotensins in Alzheimer's disease - friend or foe? Trends Neurosci 32, 619-628.

[5] Kehoe PG (2009) Angiotensins and Alzheimer's disease: a bench to bedside overview. Alzheimers Res Ther 1, 3 .

[6] Vardy ER, Rice PJ, Bowie PC, Holmes JD, Catto AJ, Hooper NM (2009) Plasma angiotensin-converting enzyme in Alzheimer's disease. J Alzheimers Dis 16, 609-618.

[7] Kauwe JS, Wang J, Mayo K, Morris JC, Fagan AM, Holtzman DM, Goate AM (2009) Alzheimer's disease risk variants show association with cerebrospinal fluid amyloid beta. Neurogenetics 10, 13-17.

[8] Kehoe PG, Katzov H, Feuk L, Bennet AM, Johansson B, Wiman B, de Faire U, Cairns NJ, Wilcock GK, Brookes AJ, Blennow K, Prince JA (2003) Haplotypes extending across ACE are associated with Alzheimer's disease. Hum Mol Genet 12, 859-867.

[9] Cambien F, Alhenc-Gelas F, Herbeth B, Andre JL, Rakotovao R, Gonzales MF, Allegrini J, Bloch C (1988) Familial resemblance of plasma angiotensin-converting enzyme level: the Nancy Study. Am J Hum Genet 43, 774-780.

[10] Rigat B, Hubert C, Alhenc-Gelas F, Cambien F, Corvol P, Soubrier F (1990) An insertion/deletion polymorphism in the angiotensin I-converting enzyme gene accounting for half the variance of serum enzyme levels. J Clin Invest 86, 1343-1346.

[11] Tiret L, Rigat B, Visvikis S, Breda C, Corvol P, Cambien F, Soubrier F (1992) Evidence, from combined segregation and linkage analysis, that a variant of the angiotensin I-converting enzyme (ACE) gene controls plasma ACE levels. Am J Hum Genet 51, 197-205.

[12] Lehman DM, Fu DJ, Freeman AB, Hunt KJ, Leach RJ, Johnson-Pais T, Hamlington J, Dyer TD, Arya R, Abboud H, Goring HH, Duggirala R, Blangero J, Konrad RJ, Stern MP (2005) A single nucleotide polymorphism in MGEA5 encoding O-GlcNAc-selective N-acetyl-beta-D glucosaminidase is associated with type 2 diabetes in Mexican Americans. Diabetes 54, 1214-1221.

[13] Corder EH, Saunders AM, Strittmatter WJ, Schmechel DE, Gaskell PC, Small GW, Roses AD, Haines JL, Pericak-Vance MA (1993) Gene dose of apolipoprotein E type 4 allele and the risk of Alzheimer's disease in late onset families. Science 261, 921-923.

[14] Saunders AM, Strittmatter WJ, Schmechel D, George-Hyslop PH, Pericak-Vance MA, Joo SH, Rosi BL, Gusella JF, Crapper-MacLachlan DR, Alberts MJ, et al. (1993) Association of apolipoprotein $\mathrm{E}$ allele epsilon 4 with late-onset 
familial and sporadic Alzheimer's disease. Neurology 43, 1467-1472.

[15] Bertram L, McQueen M, Mullin K, Blacker D, Tanzi R (2007) Systematic meta-analyses of Alzheimer disease genetic association studies: the AlzGene database. Nat Genet 39, 17-23.

[16] Katzov H, Bennet AM, Kehoe P, Wiman B, Gatz M, Blennow K, Lenhard B, Pedersen NL, de Faire U, Prince JA (2004) A cladistic model of ACE sequence variation with implications for myocardial infarction, Alzheimer disease and obesity. Hum Mol Genet 13, 2647-2657.

[17] Meng Y, Baldwin CT, Bowirrat A, Waraska K, Inzelberg R, Friedland RP, Farrer LA (2006) Association of polymorphisms in the Angiotensin-converting enzyme gene with Alzheimer disease in an Israeli Arab community. Am J Hum Genet 78, 871-877.

[18] Schjeide BM, McQueen MB, Mullin K, DiVito J, Hogan MF, Parkinson M, Hooli B, Lange C, Blacker D, Tanzi RE, Bertram L (2009) Assessment of Alzheimer's disease case-control associations using family-based methods. Neurogenetics $\mathbf{1 0}$, 19-25.

[19] Keavney B, McKenzie CA, Connell JM, Julier C, Ratcliffe PJ, Sobel E, Lathrop M, Farrall M (1998) Measured haplotype analysis of the angiotensin-I converting enzyme gene. Hum Mol Genet 7, 1745-1751.

[20] Soubrier F, Martin S, Alonso A, Visvikis S, Tiret L, Matsuda F, Lathrop GM, Farrall M (2002) High-resolution genetic mapping of the ACE-linked QTL influencing circulating ACE activity. Eur J Hum Genet 10, 553-561.

[21] Rieder MJ, Taylor SL, Clark AG, Nickerson DA (1999) Sequence variation in the human angiotensin converting enzyme. Nat Genet 22, 59-62.

[22] Kehoe PG, Russ C, Mcllory S, Williams H, Holmans P, Holmes C, Liolitsa D, Vahidassr D, Powell J, McGleenon B, Liddell M, Plomin R, Dynan K, Williams N, Neal J, Cairns NJ, Wilcock G, Passmore P, Lovestone S, Williams J, Owen MJ (1999) Variation in DCP1, encoding ACE, is associated with susceptibility to Alzheimer disease. Nat Genet 21, 71-72.

[23] McKhann G, Drachman D, Folstein M, Katzman R, Price D, Stadlan EM (1984) Clinical diagnosis of Alzheimer's disease: report of the NINCDS-ADRDA Work Group under the auspices of Department of Health and Human Services Task Force on Alzheimer's Disease. Neurology 34, 939-944.

[24] Mirra SS, Hart MN, Terry RD (1993) Making the diagnosis of Alzheimer's disease. A primer for practicing pathologists. Arch Pathol Lab Med 117, 132-144.

[25] Morgan AR, Hamilton G, Turic D, Jehu L, Harold D, Abraham R, Hollingworth P, Moskvina V, Brayne C, Rubinsztein DC, Lynch A, Lawlor B, Gill M, O’Donovan M, Powell J, Lovestone S, Williams J, Owen MJ (2008) Association analysis of 528 intra-genic SNPs in a region of chromosome 10 linked to late onset Alzheimer's disease. $\mathrm{Am}$ J Med Genet B Neuropsychiatr Genet 147B, 727-731.

[26] Wigginton JE, Cutler DJ, Abecasis GR (2005) A note on exact tests of Hardy-Weinberg equilibrium. Am J Hum Genet 76, 887-893.

[27] Purcell S, Neale B, Todd-Brown K, Thomas L, Ferreira MA, Bender D, Maller J, Sklar P, de Bakker PI, Daly MJ, Sham PC (2007) PLINK: a tool set for whole-genome association and population-based linkage analyses. Am J Hum Genet 81, 559-575.

[28] Schaid DJ, Rowland CM, Tines DE, Jacobson RM, Poland GA (2002) Score tests for association between traits and haplotypes when linkage phase is ambiguous. Am J Hum Genet 70, $425-434$
[29] Alvarez R, Alvarez V, Lahoz CH, Martinez C, Pena J, Sanchez JM, Guisasola LM, Salas-Puig J, Moris G, Vidal JA, Ribacoba R, Menes BB, Uria D, Coto E (1999) Angiotensin converting enzyme and endothelial nitric oxide synthase DNA polymorphisms and late onset Alzheimer's disease. J Neurol Neurosurg Psychiatry 67, 733-736.

[30] Edwards TL, Pericak-Vance M, Gilbert JR, Haines JL, Martin ER, Ritchie MD (2009) An association analysis of Alzheimer disease candidate genes detects an ancestral risk haplotype clade in ACE and putative multilocus association between ACE, A2 M, and LRRTM3. Am J Med Genet B Neuropsychiatr Genet 150B, 721-735.

[31] Ghebranious N, Mukesh B, Giampietro PF, Glurich I, Mickel SF, Waring SC, McCarty CA (2010) A Pilot Study of Gene/Gene and Gene/Environment Interactions in Alzheimer Disease. Clin Med Res. doi:10.3121/cmr.2010.894

[32] Helbecque N, Codron V, Cottel D, Amouyel P (2009) An age effect on the association of common variants of ACE with Alzheimer's disease. Neurosci Lett 461, 181-184.

[33] Kolsch H, Jessen F, Freymann N, Kreis M, Hentschel F, Maier W, Heun R (2005) ACE I/D polymorphism is a risk factor of Alzheimer's disease but not of vascular dementia. Neurosci Lett 377, 37-39.

[34] Mattila KM, Rinne JO, Roytta M, Laippala P, Pietila T, Kalimo H, Koivula T, Frey H, Lehtimaki T (2000) Dipeptidyl carboxypeptidase 1 (DCP1) and butyrylcholinesterase (BCHE) gene interactions with the apolipoprotein E epsilon4 allele as risk factors in Alzheimer's disease and in Parkinson's disease with coexisting Alzheimer pathology. JMed Genet 37, 766-770.

[35] Corneveaux JJ, Liang WS, Reiman EM, Webster JA, Myers AJ, Zismann VL, Joshipura KD, Pearson JV, Hu-Lince D, Craig DW, Coon KD, Dunckley T, Bandy D, Lee W, Chen K, Beach TG, Mastroeni D, Grover A, Ravid R, Sando SB, Aasly JO, Heun R, Jessen F, Kolsch H, Rogers J, Hutton ML, Melquist S, Petersen RC, Alexander GE, Caselli RJ, Papassotiropoulos A, Stephan DA, Huentelman MJ (2010) Evidence for an association between KIBRA and late-onset Alzheimer's disease. Neurobiol Aging 31, 901-909.

[36] Bruandet A, Richard F, Tzourio C, Berr C, Dartigues JF, Alperovitch A, Amouyel P, Helbecque N (2008) Haplotypes across ACE and the risk of Alzheimer's disease: the three-city study. J Alzheimers Dis 13, 333-339.

[37] Cousin E, Mace S, Rocher C, Dib C, Muzard G, Hannequin D, Pradier L, Deleuze JF, Genin E, Brice A, Campion D (2009) No replication of genetic association between candidate polymorphisms and Alzheimer's disease. Neurobiol Aging. doi:10.1016/j.neurobiolaging.2009.09.004

[38] Corneveaux JJ, Myers AJ, Allen AN, Pruzin JJ, Ramirez M, Engel A, Nalls MA, Chen K, Lee W, Chewning K, Villa SE, Meechoovet HB, Gerber JD, Frost D, Benson HL, O'Reilly S, Chibnik LB, Shulman JM, Singleton AB, Craig DW, van Keuren-Jensen KR, Dunckley T, Bennett DA, De Jager PL, Heward C, Hardy J, Reiman EM, Huentelman MJ (2010) Association of CR1, CLU and PICALM with Alzheimer's disease in a cohort of clinically characterized and neuropathologically verified individuals. Hum Mol Genet 19, 32953301.

[39] Shulman JM, Chibnik LB, Aubin C, Schneider JA, Bennett DA, De Jager PL (2010) Intermediate phenotypes identify divergent pathways to Alzheimer's disease. PLoS One 5, e11244.

[40] Miners JS, Ashby E, van Helmond Z, Chalmers KA, Palmer LE, Love S, Kehoe PG (2008) Angiotensin-converting enzyme (ACE) levels and activity in Alzheimer's disease, 
and relationship of perivascular ACE-1 to cerebral amyloid angiopathy. Neuropathol Appl Neurobiol 34, 181-193.

[41] Miners JS, van Helmond Z, Raiker M, Love S, Kehoe PG (2011) ACE variants and association with brain $\mathrm{A} \beta$ levels in Alzheimer's disease. Am J Transl Res 3, 71-78.

[42] Miners S, Ashby E, Baig S, Harrison R, Tayler H, Speedy E, Prince JA, Love S, Kehoe PG (2009) Angiotensin-converting enzyme levels and activity in Alzheimer's disease: differences in brain and CSF ACE and association with ACE1 genotypes. Am J Transl Res 1, 163-177.

[43] Ellul J, Archer N, Foy CM, Poppe M, Boothby H, Nicholas H, Brown RG, Lovestone S (2007) The effects of commonly prescribed drugs in patients with Alzheimer's disease on the rate of deterioration. J Neurol Neurosurg Psychiatry 78, 233239.

[44] Chung CM, Wang RY, Chen JW, Fann CS, Leu HB, Ho HY, Ting CT, Lin TH, Sheu SH, Tsai WC, Chen JH, Jong YS, Lin SJ, Chen YT, Pan WH (2010) A genome-wide association study identifies new loci for ACE activity: potential implications for response to ACE inhibitor. Pharmacogenomics $J \mathbf{1 0}$ 537-544.

[45] Khachaturian AS, Zandi PP, Lyketsos CG, Hayden KM, Skoog I, Norton MC, Tschanz JT, Mayer LS, Welsh-Bohmer KA, Breitner JC (2006) Antihypertensive medication use and incident Alzheimer disease: the Cache County Study. Arch Neurol 63, 686-692.

[46] Li NC, Lee A, Whitmer RA, Kivipelto M, Lawler E, Kazis LE, Wolozin B (2010) Use of angiotensin receptor blockers and risk of dementia in a predominantly male population: prospective cohort analysis. BMJ 340, b5465.

[47] Ohrui T, Matsui T, Yamaya M, Arai H, Ebihara S, Maruyama M, Sasaki H (2004) Angiotensin-converting enzyme inhibitors and incidence of Alzheimer's disease in Japan. J Am Geriatr Soc 52, 649-650.

[48] Ohrui T, Tomita N, Sato-Nakagawa T, Matsui T, Maruyama M, Niwa K, Arai H, Sasaki H (2004) Effects of brainpenetrating ACE inhibitors on Alzheimer disease progression. Neurology 63, 1324-1325.

[49] Rozzini L, Chilovi BV, Bertoletti E, Conti M, Del Rio I, Trabucchi M, Padovani A (2006) Angiotensin converting enzyme (ACE) inhibitors modulate the rate of progression of amnestic mild cognitive impairment. Int J Geriatr Psychiatry 21, 550-555.

[50] Rozzini L, Vicini Chilovi B, Trabucchi M, Padovani A (2008) Antihypertensive medications influence the rate of conversion from mild cognitive impairment to Alzheimer disease. Arch Neurol 65, 993-994; author reply 994-995.

[51] Sink KM, Leng X, Williamson J, Kritchevsky SB, Yaffe K, Kuller L, Yasar S, Atkinson H, Robbins M, Psaty B, Goff DC Jr (2009) Angiotensin-converting enzyme inhibitors and cognitive decline in older adults with hypertension: results from the Cardiovascular Health Study. Arch Intern Med 169, 1195-1202. 